\title{
Multiple Audiences as Text Stakeholders: A Conceptual Framework for Analyzing Complex Rhetorical Situations
}

\author{
Rudi Palmieri ${ }^{1} \cdot$ Sabrina Mazzali-Lurati $^{2}$
}

Published online: 2 March 2016

(C) The Author(s) 2016. This article is published with open access at Springerlink.com

\begin{abstract}
In public communication contexts, such as when a company announces the proposal for an important organizational change, argumentation typically involves multiple audiences, rather than a single and homogenous group, let alone an individual interlocutor. In such cases, an exhaustive and precise characterization of the audience structure is crucial both for the arguer, who needs to design an effective argumentative strategy, and for the external analyst, who aims at reconstructing such a strategic discourse. While the peculiar relevance of multiple audience is often emphasized in the argumentation literature and in rhetorical studies, proposals for modelling multi-audience argumentative situations remain scarce and unsystematic. To address this gap, we propose an analytical framework which integrates three conceptual constructs: (1) Rigotti and Rocci's notion of communicative activity type, understood as the implementation of an interaction scheme into a piece of institutional reality, named interaction field; (2) the stakeholder concept, originally developed in strategic management and public relations studies to refer to any actor who affects and/or is affected by the organizational actions and who, accordingly, carries an interest in them; (3) the concept of participant role as it emerges from Goffman's theory of conversation analysis and related linguistic and media studies. From this integration, we derive the notion of text stakeholder for referring to any organizational actor whose interest (stake) becomes an argumentative issue which the organizational text must account for in
\end{abstract}

Rudi Palmieri

rudi.palmieri@liverpool.ac.uk

Sabrina Mazzali-Lurati

sabrina.lurati@usi.ch

1 Department of Communication and Media, School of the Arts, University of Liverpool, 19-23 Abercromby Square, Liverpool L69 7ZG, UK

2 Institute of Argumentation, Linguistics and Semiotics, USI-University of Lugano, Via Buffi 13, 6904 Lugano, Switzerland 
order to effectively achieve its communicative aim. The text stakeholder notion enables a more comprehensive reconstruction and characterization of multiple audience by eliciting the relevant participants staged in a text and identifying, for each of them, the interactional role they have, the peculiar interest they bear and the related argumentative issue they create. Considering as an illustrative case the defense document issued by a corporation against a hostile takeover attempt made by another corporation, we show how this framework can support the analysis of strategic maneuvering by better defining the audience demand and, so, better explaining how real arguers design and adapt their topical and presentational choices.

Keywords Addressee - Activity type - Argumentation - Audience analysis · Interaction field · Multiple audience $\cdot$ Polylogue $\cdot$ Ratified participants $\cdot$ Rhetorical situation $\cdot$ Stakeholders $\cdot$ Strategic communication $\cdot$ Takeovers

\section{Introduction}

Between 2006 and 2012, Dublin-based low-cost airline company Ryanair made three attempts to take control of Aer Lingus, the Irish national flag carrier. All Ryanair's offers were hostile, which means that the shareholders of the target company (Aer Lingus) were asked to sell their shares to the bidder (Ryanair) notwithstanding opposition from the target Board of directors (see Palmieri 2014). Indeed, the directors of Aer Lingus severely criticized Ryanair's proposal and recommended shareholders to reject it by advancing arguments such as "Ryanair's Offer does not reflect Aer Lingus' true value"; "[the offer] is ill-conceived, contradictory and anti-competitive"; "[the offer] ignores our excellent prospects as an independent company" (Aer Lingus, Defense document, 3.11.2006, p. 22). The first offer, announced on October 5th, 2006, was withdrawn by Ryanair itself after the European Competition Commission started an investigation aimed at verifying possible antitrust issues. The two companies were, in fact, direct competitors in the Irish and British airline industry. Moreover, Ryanair was holder of $29.9 \%$ of Aer Lingus shares, ${ }^{1}$ while the Irish Government ${ }^{2}$ and Aer Lingus employees ${ }^{3}$ possessed 25 and $14 \%$ respectively of the shares. Ryanair also withdrew its second offer, made in December 2008, in light of the announcement of rejection by the Irish Government. The third offer (June 2012) was prohibited in February 2013 by the European Commission, again for antitrust reasons.

\footnotetext{
1 When control of a corporation is pursued by means of a hostile offer, the bidder often acquires just less than $30 \%$ of the target shares before making the offer. This is because $30 \%$ is the threshold below which the bidder is free to buy shares in the market without any obligation towards other shareholders. Pursuant to Art 9.1 of the UK City Code on Takeovers and Mergers, any person holding $30 \%$ or more of the shares of a company is bound to make a mandatory offer for all the shares paying the same price for all of them.

2 On October 2006, government-owned Aer Lingus made an Initial Public Offering becoming a publiclylisted corporation with the Irish government retaining a $28 \%$ stake.

3 The employees of Aer Lingus hold shares of the company by participating in an Employee Stock Option Trust (ESOT), which acquires shares in a company and distributes them to the company employees.
} 
The Ryanair-Aer Lingus saga brings to light, in particular, a crucial aspect, which is inherent not only in takeovers and their argumentative interactions (Palmieri 2008; Brennan et al. 2010), but also in numerous other types of argumentative activity: in designing arguments aimed at justifying a standpoint that should be advanced and defended in a public context, organizational actors such as corporate or political leaders need to account for the presence of a multiple audience, made up of different groups of people simultaneously reading/listening to the argumentative discourse. The takeover proposal made by Ryanair did not just concern the shareholders of Aer Lingus. Antitrust authorities (the EU Competition Commission), the Irish government and the Aer Lingus employees, just to mention a few, were also involved and some of these actors were equally as important as investors (or even more so) in determining the outcome of the offer. In similar rhetorical situations, the intended reader (Jameson 2000) actually corresponds to a plurality of interagents, directly or indirectly involved in the situation. In fact, both public and private institutions regularly publish numerous texts (e.g. press releases, advertisements, annual reports, financial statements, etc.) that address several different groups of people, for whom the meaning and implications of the message is not necessarily the same. Thus, an exhaustive and precise definition and characterization of the audience structure of a public argumentative discourse is crucial both for the arguer, who needs to design an effective argumentative strategy, and for the external analyst, who aims at reconstructing such a strategic discourse.

Argumentation studies, especially those including a rhetorical concern, have strongly emphasized the central role of audience in argumentative discourse (Perelman and Olbrecths-Tyteca 1969; Tindale 2004; van Eemeren 2010). However, relatively scarce consideration has been given to the analysis of multiaudience situations. This paper sets out to propose an analytical framework for the identification and reconstruction of the audience structure in those argumentative texts where the author is evidently confronted with a multiple audience situation. Our proposal centers on the management concept of stakeholder (see later), but elaborates further such a concept by emphasizing its inherently communicative, more specifically argumentative, dimension. Thus, we derive the notion of text stakeholder, understood as a social actor, whose peculiar interest (stake) in the organizational activity under discussion creates an argumentative issue, which organizational leaders have to resolve by maneuvering strategically (see van Eemeren 2010). In other words, the organizational text must acknowledge all specific issues implicitly or explicitly raised by all text stakeholders as well as the interactional role each of them occupies in order to effectively achieve its communicative aim corresponding to the rhetorical exigence (see Bitzer 1968, 1980) motivating organizational writing.

In the next section, we review relevant existing literature on the problem of multiple audience to better circumscribe the gap this paper aims at filling. Section 3 elaborates the notion of text stakeholder, which in Sect. 4 will be applied to the Ryanair-Aer Lingus case. We conclude in Sect. 5 with some reflections on possible applications of this notion to the analysis and evaluation of argumentation in context. 


\section{Reconstructing Multiple Audience: Relevant Contributions}

\subsection{The Centrality of Audience in the Design of Argumentative Interactions}

Ever since Ancient Rhetoric, the centrality of the audience for the analysis and the design of argumentative interventions in public arenas has been strongly emphasized. Accounting for "the nature of our particular audience" when approaching public discourse is one of the fundamental principles in Aristotle's Rhetoric (Ret. I, 9, see Ross 1959) and is reaffirmed in subsequent Latin rhetorical treatises. In the Rhetorica ad Herennium (see Caplan 1954), the topic is dealt with particularly in relationship to the discourse's exordium, where the rhetor has to face the crucial task (officium) of obtaining a receptive (docilem), benevolent (benivolum), and attentive (attentum) hearer. In Partitiones oratoriae, the necessity of taking into consideration the opinions of the hearers (1942: $\S 90$ ) leads Cicero to point out the need to speak differently to different classes of men (Cicero 1942: $\S 90$; also quoted in Perelman and Olbrecths-Tyteca 1969: 20) and to underline that it is precisely this ability of audience adaptation that demonstrates the rhetor's eloquence (Cicero 1962: XXXV-XXXVI quoted in Kerbrat-Orecchioni 2004: 16-17). Similarly, Quintilian stresses the importance of considering who the members of the assembly are and which differences exist among them when dealing with deliberative discourse. Important factors to be considered are "sex, dignity and age", but, he points out, "it is the character of our hearers that should lead us to make the chief difference in our addresses to them" (Inst. Or. III, 8, 38, see Winterbottom 1970).

The reflections made by the abovementioned classical authors have been recovered by contemporary linguists and argumentation scholars. According to Bakhtin (1982), discourse (and particularly rhetorical discourse) always has a dialogic nature: it "always is oriented towards an addressee and his/her explicit and implicit response" and it "is internally constructed to anticipate the addressee's reactions and objections" (Rocci 2009: 266). In the New Rhetoric, Perelman and Olbrecths-Tyteca (1969) maintain that the contact between the speaker and his/her audience is one of the preliminary conditions to argumentation as well as a necessary aspect in order to develop argumentation (2010: 18-19). As Tindale suggests, "[a]t the core of any account of argumentation that gives prominence to rhetoric is a fundamental accommodation of audience" (2006: 452), where audience-Tindale observes - has to be understood not only as the intended audience (as Perelman and Olbrechts-Tyteca mainly do), but also as actual audience (2006: 453). ${ }^{4}$ Audience is a constitutive element of Bitzer's notion of rhetorical situation (1968), which also comprises the rhetor's exigence, i.e. the imperfection marked by urgency which can be removed only if discourse is introduced into the situation, and a set of constraints, "which influence the rhetor and can be brought to

\footnotetext{
4 Some relevant works in rhetoric and composition also deal with rhetorical situations in which audience is multiple. Duncan identified "five kinds of audience we must court" (1962: 292), Flower distinguished between primary audience and one or more secondary audiences (1981: 160-163, cf. also Ede 1984) and Park provided a definition of the four meanings of audience of a text, based on the distinctionfundamental in the rhetorical research on that topic (cf. Ede and Lunsford 1984) - between audience outside the text and audience inside the text (1982: 249-250).
} 
bear upon the audience" (1968: 5-6). According to Bitzer, an audience is truly rhetorical only if it has the possibility and capability to act as mediator of change, thereby positively modifying the rhetor's exigence (1968: 8). In this respect, Bitzer distinguishes the rhetorical audience from "a body of mere hearers and readers" (1968: 8), who are neither affected by the discourse nor can they affect the exigence of the rhetor. As we shall explain in more depth in Sect. 3, this remark is extremely relevant for the approach we are developing in this paper: someone should be considered as a relevant audience when (1) he/she holds an interest in the content of the rhetorical discourse; and (2) the rhetor is significantly interested in the effect that the rhetorical discourse produces on him/her. ${ }^{5}$

Although that of audience is normally seen as a rhetorical concept, its relevance, also from a dialectical point of view, should not be neglected. In a regulated argumentative discussion, the acceptability of the standpoint at issue is, in any case, submitted to the critical scrutiny of the antagonist/opponent (see van Eemeren and Grootendorst 2004). At the evaluative level, the reasonableness of any dialectical move supporting a doubtful standpoint also depends on its being grounded in material and procedural starting points that the protagonist and the antagonist share (van Eemeren 2010). In some cases, the responsibility for the fallaciousness of an arguer's move may even be attributed, at least partly, to the interlocutor and his/her uncooperative or uncritically engaged behavior (Jacobs and Jackson 2006). With a view to integrating their dialectical framework with rhetorical insights, pragmadialecticians have singled out adaptation to the audience demand as one of the three inseparable aspects (the other two being the choices from the topical potential and the use of presentational devices) of strategic maneuvering, i.e. the arguer's effort to simultaneously achieve dialectical reasonableness and rhetorical effectiveness (van Eemeren and Houtlosser 2002; van Eemeren 2010). Hence, the discussant who plays the dialectical role of antagonist in a critical discussion represents, from the rhetorical viewpoint, the main audience of the protagonist's argumentation. This is implicitly acknowledged by Aristotle every time he gives advice on dialectical moves according to the characteristics and behaviors of the antagonist (the "respondent"). For instance, he recommends postponing, as far as possible, the explicit advancing of the standpoint when debating with a biased opponent (Topica, VIII, I; see Ross 1958; van Rees and Rigotti 2011). In this case, it is clear that the rhetorical aim of persuading the interlocutor by securing a shared premise goes along with the dialectical aim of encouraging a critical attitude toward the standpoint (see Jacobs 2000). Reasonable argumentation is, therefore, always "audience-directed" (Tindale 2004: 140). As posited by normative pragmatics (van Eemeren et al. 1993), an argumentative strategy addresses audience with "a design

\footnotetext{
5 Bitzer further develops on the existence of a multiple audience, by introducing the distinction between audience and public (Bitzer 1978). Reflecting on public rhetoric, Bitzer observes that often, in public rhetorical discourse, audience and public do not coincide because "[...] public rhetorical discourse is representational": "persons represent others by means of discourse and action" (1978: 73). Both the public speaker and the audience can stand in for a wider public and, therefore, they "must be capable of rich sympathetic understanding and feeling which virtually unites him with that public" and must "possess the knowledge and interests of his public" (1978: 74-75).
} 
of intervention aimed at favoring the critical examination of a doubtful proposition in view of reaching an agreement" (Jacobs 2009).

\subsection{Dealing with Multi-audience Rhetorical Situations}

Referring to the difficulty in determining by purely material criteria what constitutes a speaker's audience, Perelman and Olbrechts-Tyteca observe, in the first place, that this "difficulty is even greater in the case of a writer's audience, as in most cases it is impossible to identify his readers with certainty" (1969: 19). Secondly, they point out that, in several rhetorical situations, different listeners are present whom the speaker takes into consideration to a differing extent and in different ways, by according each of them-and their needs, opinions and interests - a different degree of importance. Perelman and Olbrechts-Tyteca remark that several rhetorical situations envisage a composite audience "embracing people differing in character, loyalties, and functions" and requiring the orator to use "a multiplicity of arguments" (1969: 21-22).

These reflections bring to light the central issue of this paper, namely the presence of a multiple audience in the context of an argumentative speech event and the influence that such a multiple audience may have on the strategic design of argumentation. It is an issue that has caught the attention especially of scholars in speech communication and rhetoric, who have investigated rhetorical strategies in well-known and historically important texts (see Jasinski 2001). Benoit and D'Agostine (1994) start precisely with the question of "what a rhetor can do when facing multiple audiences" (p. 89). They analyze the case of Justice Marshall's opinion in Marbury v. Madison to illustrate a form of integration strategy where the end desired by one audience is incorporated as the means to an end desired by another audience. Benoit and D'Agostine (p. 96) identify three "key audiences" of Marshall's opinion - the Supreme Court (i.e. those directly involved in the judicial case), the Federalists and the Anti-Federalists-without referring to any generalizable theoretical basis to characterize and distinguish them. A similar gap can be found in Myers (1999), who develops a close reading of Ernest Bevin's 1945 speech on the subject of British policy toward Palestine. Leaving out any precise definition, the author distinguishes what he calls the "immediately present audience" (i.e. the British House of Commons) from a series of "attentive audiences" (e.g. the British Chiefs of Staff; the American Government, etc.) and the "undefined public" of "world opinion" (p.60).

Given the importance of considering audience demand when maneuvering strategically, van Eemeren concentrates on "the problem of identifying the audience that is supposed to be reached and next on the problem of cataloguing their relevant views and references" (2010: 108). In doing so, he recognizes the complexity of the audience structure and makes important distinctions. The first important distinction is that of primary and secondary audience, where the former is the "audience the arguer considers the more important to reach" (2010: 109) while the latter consists of "persons instrumental in reaching [the primary audience]" (ibidem). As an illustrative example, van Eemeren considers a television debate between two politicians where the primary audience are the viewers while the opposite side is the 
secondary audience. While the primary and secondary audiences so distinguished can be singled out as two clearly distinct groups of people, van Eemeren remarks that "audiences-whether primary or secondary-are not always homogenous" (ibidem). Accordingly, he speaks in these cases of composite audience and, more specifically, of multiple audience when the addressees have different positions and of mixed audience, when they have different starting points. ${ }^{6}$

From a strictly dialectical perspective, the complexity of the audience structure means, at least, that more than one argumentative interaction has to be reconstructed. Recently, Aakhus and Lewinski (Aakhus and Lewinski 2011; Lewinski and Aakhus 2014) have tackled the issue of how to analyze and evaluate polylogues from a dialectical viewpoint i.e. multi-party discussions, which arise "whenever different speakers take up and discuss more than two positions (standpoints)" (Lewinski and Aakhus 2014: 162). These authors reflect on the challenges posed by polylogues on dyadic (proponent/opponent; protagonist/ antagonist) models and dialogue types. Their chief concern is to assess the capacity of existing dialectical models-mainly the pragma-dialectical critical discussion ideal-in supporting the analysis and evaluation of polylogues. This research problem appears to be particularly urgent when studying large-scale public debates which new communication technologies have made possible over the last years (see Aakhus and Vasilyeva; 2008; Aakhus and Lewinski 2011; Lewinski 2010).

Whether and how traditional dialectical models and dialogue types have to be adapted or modified to examine multi-participant argumentation remains an open question, which exceeds the scope of this paper. There is no doubt that the RyanairAer Lingus case, and takeover stories in general, typically give rise to a relatively large-scale public debate where more than two parties become protagonists of argumentatively-relevant moves. ${ }^{7}$ However, this paper does not aim at reconstructing the polylogues emerging from a takeover case and the interconnected texts composing it. Rather, our focus is on the single text that one company-the target firm in our case-has to design and publish at a precise moment of the controversy to respond to a precise situation. In other words, this paper tackles the problem that Benoit and D'Agostine define as "the problem of persuading multiple audiences within a single message" (1994: 89) and Myers as the "situation a speaker faces when two or more of these audience types are addressed in one speech" (1999: 51). Thus, our analytical perspective considers the organization as the author of a text, which simultaneously pursues a set of rhetorical goals in relation to different interagents involved. Indeed, more often than not, written communication in organizations (both internal and external) is addressed at a multiple audience (Huettman 1996; Schriver 1992). The notion of text stakeholder, which we elaborate in the next section, is aimed at defining the audience structure of this macro-genre of

\footnotetext{
${ }^{6}$ We observe that in van Eemeren the term "multiple audience" acquires a more specific value compared to the use of the same notion in rhetorical studies. We shall come back to this point in Sect. 3 when discussing our theoretical proposal.

7 Palmieri (2014) has clearly shown that hostile takeovers especially envisage an interconnected series of speech events involving several competing parties, which react to a precedent speech event (see also Cooke et al. 1998; Brennan 1999; Palmieri 2008).
} 
texts, which, besides takeover defense documents, includes documents such as annual reports, letters to customers, or central bankers' speeches.

\section{Audiences as Text Stakeholders}

In this section, we develop the notion of text stakeholder-initially proposed in a less elaborated form by Mazzali-Lurati (2011) — as a conceptual framework, which supports the analytical identification, segmentation and characterization of the audiences of an argumentative intervention in a public context. To this end, we integrate insights from different disciplinary fields, in particular: (1) Rigotti and Rocci's notion of communicative activity type, understood as the implementation of an interaction scheme into a piece of institutional reality, named interaction field (Sect. 3.1); (2) the concept of participant role in conversation as it emerges in particular from Goffman's works (Sect. 3.2); (3) the stakeholder concept, developed in strategic management and public relations studies (Sect. 3.3). We then show how this conceptualization of an argumentative audience can help differentiate among different types of audience structure (Sect. 3.4).

\subsection{Communicative Activity Types: The Scheme and the Field Components}

Our notion of text stakeholder encompasses two distinct (though related) dimensions that, in our view, should be taken into account when singling out and characterizing audiences. Firstly, audiences participate in the text by taking a particular interactional role. Secondly, besides occupying a participatory slot envisioned by the structure of the communicative activity at hand, each audience holds a particular stake, an interest bound to the social goals pursued by the activity type that the text refers to. Audiences are present in the text-in our case the takeover defense document - to the extent that they bear a particular interest, which the author-in our case the Board of directors of the target company-is expected and needs to account for.

The text stakeholder's participation role and stake both depend on the communicative activity type and, more specifically, on the situation in which the text intervenes. Rigotti and Rocci (2006) conceive of a (communicative) activity type as the "mapping of an interaction scheme onto an interaction field" (p.172). The interaction field is the concrete piece of institutional reality [i.e., an actual piece of social reality-an institution in Searle's terms (Searle 1995)] defined by hierarchically organized shared goals and mutual commitments (Rigotti and Rocci 2006: 172). It is the social space where organizational stakeholders "live". Their interest is bound to the goals and commitments exchanged in the field, which assigns social roles, i.e. "bundles of pre-existing commitments that constrain the possibilities of interaction" (p. 172). The activity (and the text realizing it) represents an attempt to modify the field while at the same time being constrained by the goals and norms of the field. Interaction schemes are "culturally-shared recipes for interaction congruent with more or less broad classes of joint goals and involving scheme-roles presupposing generic requirements" (p. 173). An interaction 
scheme is a design of abstract communicative roles and flows, which communicative actors activate in the interaction field in order to achieve their shared goals. Typical examples of interaction schemes are deliberation, negotiation, mediation, lecturing (see also van Eemeren 2010 and the similar notion of genre of communicative activities). For example, the activity type of shareholder meeting applies the scheme of deliberation with the precise field being the business corporation.

The field-independency of interaction schemes is proven by the evidence that the use of the same scheme can be observed in different fields. Deliberation, in fact, is applied in many different fields such as parliaments, faculty meetings, town councils, etc. (see Rocci et al. 2015). Activity types impose on arguers various types of constraints on the performance of speech acts. At the argumentative level, these constraints affect, in particular, the options for designing rhetorically-effective argumentative strategies - van Eemeren refers to these constraints as institutional preconditions of strategic maneuvering (van Eemeren 2010: 152-155). Some of these preconditions depend on the format of the interaction scheme.

Rigotti and Rocci (2006) consider activity types (see also Levinson 1979/1992) as the institutionalized dimension of the context of a simple or complex speech act (p. 171). Their model of communication context combines the institutionalized dimension of the activity type with an interpersonal dimension, which includes personal stories and relationships and communal aspects such as organizational myths, rites and models (pp. 174-175). Indeed, the communication roles and flows created by the mapping of schemes onto fields are implemented by real people whose actual interests and concerns may easily exceed the goals and commitments shared at the institutional level. Therefore, an arguer who knows the deep personal interests of the readers/hearers would have the chance to improve the effectiveness of his/her discourse towards the audience demand. However, this level of knowledge, which is often not available for the discourse designer, does not necessarily count as a relevant starting point for organizational argumentation. Organizational actors such as corporate directors are bound to the interaction field by an agency relationship according to which the agent is expected to act on behalf of the principal, not in absolute terms, but in relation to a precise type of mandate, normally established in a contractual form (see Ross 1973; Eisenhardt 1989). Thus, in the interaction field of listed corporations, directors have a duty to act in the best interests of shareholders, where the latter are understood to be holders of a portion of ownership granting them some defined rights (such as voting on some corporate issues, receiving dividends, etc.) and not as real individual persons who might have further desires, interests and cultural backgrounds. If any shareholder has peculiar interests which conflict with the economic interest or other primary objectives of the company, this would be a private matter which directors cannot be expected to fulfill de jure. Similarly, if one member of the Board and one shareholder are good friends and the former supports the recommendation to accept a takeover offer with a side payment, this evidently could not count as a relevant and admissible public argument. Therefore, when organizations aim at producing written texts addressing multiple audiences, what really matters as relevant context is the institutionalized dimension represented by the interaction field. 
In the perspective of Rigotti and Rocci's model of context, an argumentative situation should be seen as a sort of "picture" of the interaction field taken at a precise moment of the "life" of the activity type and representing the status of the commitments in that moment. In general, in fact, an activity can be defined as a scheme-based intervention into reality which starts from an initial situation (see van Eemeren 2010; Walton and Krabbe 1995) and evolves by changing social reality ${ }^{8}$ (the interaction field) to obtain a new situation-a possible and more desirable state of affairs (Rigotti 2008) - broadly coinciding with the goal of the actors involved and, in the specific case of an argumentative activity, with the issue derived from the rhetorical exigence.

\subsection{Text Participants and Their Interactional Roles}

The structure of the audience is significantly determined by the format of the interaction scheme, which pre-configures interactional roles that different institutional actors are expected to fill. All interactional roles characterizing the communicative event represented by the text should be compatible with the interaction scheme activated by the writer. While some schemes typically project a dyadic interaction (e.g. medical or financial consultation), other schemes require the involvement of more than two communicative roles (e.g. dispute mediation, see Greco Morasso 2011).

In order to identify and distinguish the different interactional roles that audiences can assume within a text, relevant insights can be found in the work done by Goffman and later by other scholars in linguistics and media studies. The main concern of these studies is to overcome the canonical dyadic model of communication (De Saussure 1995; Shannon and Weaver 1963; Jakobson 1968), which basically assumes that meaning is produced (encoded) by the sender and interpreted (decoded) by the receiver, while many social interactions entail more participant roles (Dynel 2010; Kerbrat-Orecchioni 2004).

By reflecting on common situations of face to face conversation, ${ }^{9}$ Goffman (1981) observed that behind the words 'speaker' and 'hearer' different roles are hidden. The former may comprise three distinct persons ${ }^{10}$ : (1) the animator, i.e. "an individual active in the role of utterance production" (p. 144); (2) the author, i.e. "someone who has selected the sentiments that are being expressed and the words in which they are encoded" (ibid.); (3) the principal, i.e. "someone whose position is

\footnotetext{
${ }^{8}$ Obviously, here we are not referring to physical activities, but to symbolic activities, which "update" the commitment store (Hamblin 1970) by modifying interpersonal and/or institutional commitments. Physical activities (e.g. moving a table, building a house) mainly change the material world rather than the social-institutional world (see Palmieri and Palmieri 2012).

${ }^{9}$ Goffman rightly distinguishes the audiences of platform monologues-similar to those considered in our paper-from fellow conversationalists who can exchange turns in the context of a social gathering (1981: 137-139). At the same time, however, he observes that in both cases the participation framework can go well beyond the mere speaker-hearer or writer-reader dyadic scheme.

${ }^{10}$ Aiming at capturing the peculiarities of news media language and news language production, Bell (1984, 1991) proposes including, besides the roles of animator, author and principal, also the role of editor, i.e. of "the individual who checks the text drafted by the authors and eventually modifies it" (Bell 1991: 37).
} 
established by the words that are spoken, someone whose beliefs have been told, someone who is committed to what the words say" (ibid.). ${ }^{11}$

Although the complexity behind the speaker/writer's identity can also contribute to explaining the linguistic properties and strategic choices exhibited by organizational texts, the distinctions recalled above are less relevant for our paper, which focuses on the composition of the hearer/reader. In this regard, Goffman points out that, besides the addressed recipient (or addressee), we must consider two other types of participants ${ }^{12}$ :

1. one or more unaddressed recipients who hold an official status as ratified participants in the interaction (see also McCawley 1999: 596) ${ }^{13}$;

2. one or more unratified participants or bystanders. These are adventitious participants, whose access to the encounter, however minimal, is itself perceivable by the ratified participants (addressee included). Bystanders are further distinguished into overhearers, ${ }^{14}$ who "temporarily follow the talk, or catch bits and pieces of it, all without much effort or intent" and eavesdroppers ${ }^{15}$ who "surreptitiously exploit the accessibility they have [to the encounter]" (Goffman 1981: 132).

These distinctions may significantly influence the author's design of the message. Goffman highlights the possibility of performing subordinate communication, ${ }^{16}$ in various forms such as byplay, crossplay and sideplay, which can be accomplished

\footnotetext{
11 As Goffman notes, "[w]hen one uses the term 'speaker', one often implies that the individual who animates is formulating his own text and staking out his own position through it: animator, author, and principal are one" (1981: 145). However, it happens very often that these three different functions are undertaken by different persons, especially in organizational communication where the writing process is usually a collaborative activity (cf. Cross 1994, 2001).

12 On the reception side, Bell adds the role of referees, i.e. "third persons not physically present at an interaction, but possessing such salience for a speaker that they influence speech even in their absence" by pushing the speaker in "diverg[ing] away from the style appropriate to their addressee" towards that of the referee (Bell 1991: 127).

13 Goffman specifies that, while "[t]he ratified hearer in two-person talk is necessarily also the 'addressed' one, that is, the one to whom the speaker addresses his visual attention and to whom, incidentally, he expects to turn over the speaking role" (Goffman 1981: 133), in interactions with three or more official participants "the speaker will, at least during periods of his talk, address his remarks to one listener, so that among official hearers one must distinguish the addressed recipient from 'unaddressed' ones" (Goffman 1981: 133).

14 In written communication, an overhearer would correspond to an overreader, i.e. one who was not expected to (necessarily) read the text but, as a matter of fact, obtains access to it. For example, consider the case of communication scholars who collect and examine corporate documents for scientific purposes. The authors of the text might either have not imagined this possibility or simply not have considered this readership to be particularly relevant.

15 Evidently, the more a written or oral text is made public, the more the existence of eavesdroppers is unlikely. In other words, the presence of eavesdroppers presupposes that access to the text is restricted.

16 "Once the dyadic limits of talk as breached, and one admits bystanders and/or more than one ratified recipient to the scene, then "subordinate communication" becomes a recognizable possibility: talk that is manned, timed, and pitched to constitute a perceivedly limited interference to what might be called the "dominating communication" in its vicinity" (Goffman 1981: 133).
} 
openly or even in a concealed way, thus giving rise to collusive subordinate communication (Goffman 1981: 133-134).

Starting from Goffman's theory, other scholars have made further relevant reflections concerning in particular the central notions of 'participation' and 'ratification', both extremely important when determining and characterizing audiences and their status.

Clark and Carlson (1982) discuss standard speech act theory pointing out that what Searle and others refer to as the hearer is actually only the addressee of the illocutionary act. There are, instead, other hearers, toward whom the speaker performs an informative act. These are named side participants and broadly coincide with the category of ratified participants explained above. By contrast, both overhearers and eavesdroppers (i.e. bystanders) are considered as non-participants because the speaker intends to consider them as such: "[they] are the hearers who are NOT intended by the speaker to 'take part in' the illocutionary act, in the favored sense of 'take part in', but who are nevertheless listening" (p. 343).

Levinson (1988) also discusses the notion of participant, which for him "has something to do with what Goffman calls a 'ratified role' in the proceedings, and presupposes CHANNEL-LINKAGE or ability to receive the message" (p. 174). In her introduction to the study of polylogues, Kerbrat-Orecchioni (2004) recalls Bell's proposal of conceiving the different participation status "as concentric rings" (Bell 1991: 91), ${ }^{17}$ arguing for the "existence of different degrees of participation" (Kerbrat-Orecchioni 2004: 12), as well as for the existence of different degrees of ratification (in relation to the distinction between ratified and unratified participants; ibid. 12-13) and of different degrees of address (in relation to the distinction between addressed and non-addressed recipients; ibid., 13-14). Besides the categories derived from Goffman, Kerbrat-Orecchioni also includes in the participation framework Levinson's category of target, corresponding to the category of intended recipient introduced by McCawley (1999). This category identifies "those whom the 'speaker' intends to hear/read and understand the utterance" (1999: 596) and is accompanied by the category of recipient (in general), i.e. "persons who hear/read the utterance, irrespective of what the 'speaker' intends or is even aware of" (ibid.). The relevance of the speaker's intention is emphasized by Dynel (2010, 2011), who maintains that, besides the potential attitude of listening by a given participant, the speaker's intention to communicate meaning to a given participant is the theoretical discrimination for ratifying him/her (2010: 26).

The emphasis placed on how participants' intentions and behaviors affect and define the participation framework relates to what Clark and Carlson (1982; see also Clark 1992: 201) as well as Bell (1984: $158 \mathrm{ff}$.) refer to as audience design. When communicating, speakers are aware of and take into consideration the different "modes" of understanding by the different types of listeners (Clark 1992: 202) and design their message accordingly by considering the salience of the different

\footnotetext{
17 In his classification of the different participants' roles in news media discourse, Bell proposes viewing the different roles in the audience (namely, addressee, auditor, overhearer and eavesdroppers) «as concentric rings» that «are ranked according to whether the persons are known, ratified and/or addressed by the speaker» (Bell 1991: 91). These rings stay in a hierarchy, depending on their distance from and salience for the speaker (ibid., p. 160).
} 
participants as well as their distance from the speaker (Bell 1984: 160). At the same time, Kerbtrat-Orecchioni suggests that receivers also collaborate in fixing the attribution of roles, as, with their behavior, (e.g. refusing eye-contact, displaying a relative lack of involvement), they might accept or refuse the participation status accorded to them by the speaker (Kerbrat-Orecchioni 2004: 18).

Alongside participants' intentions and behaviors, context plays a fundamental role in shaping the participation roles. Goffman particularly highlights this, by pointing out that the social situation has a "structural significance" for talk (Goffman 1981: 136). As a matter of fact, any attempt to shape the audience by the speaker/writer is always conditioned by the constraints and affordances created by contexts. For instance, in the activity type of the shareholders meeting, the attribution of the role of addressee to shareholders is independent of the speaker's intention: it is necessarily established by the context. By contrast, the more informal activity type of dinner table conversation allows one speaker to assign different roles to the different participants in the communicative event.

The focus on context as the fundamental criterion for the attribution of roles is particularly relevant in the case of written organizational communication, where the attribution of roles cannot, or can only (very) partially, be designed by the writer. The roles in the interaction scheme and their mapping onto roles of the interaction field are clearly defined "in advance" and leave very little (often, even, no) leeway for the writer.

Based on this fundamental premise, Mazzali-Lurati (2011) —and later MazzaliLurati and Pollaroli (2013)_recovers and integrates Goffman's approach to elaborate on the classification of the different participants involved in organizational written communication. On the production side, her classification comprises three categories of communicative interagents, identical to Goffman's proposal (animator, author and principal), while on the reception side, two further types of readers are added to Goffman's list (see above): gatekeepers, those who have the institutional power of deciding on the diffusion of the text to readers (see White 1997; Shoemaker and Vos 2009; Illia et al. 2013); regulators, those who, within the interaction field, have the authority to discipline and supervise the manner in which the organizational texts is written, given certain rules established within the same field. As we shall better explain in the next section, Mazzali-Lurati proposes to refer to all these types of participants as the stakeholders of the text, as each of them "has an interest in the communicative success of the text" (Mazzali-Lurati and Pollaroli 2013: 245).

Figure 1 shows a classification of the receivers-readers of an organizational text adapted from the previously explained theoretical account, which this paper further refines. First of all, we distinguish ratified readers from over-readers, where the latter coincide with those who are neither expected nor legitimately allowed to have access to the text. They can happen to come-directly or indirectly-into contact with the text, but they are not entitled to take part in the communicative interaction because the role they cover is not envisaged by the interaction scheme. Normally, their stake in the interaction field is not relevant in respect to the rhetorical exigence and, therefore, they do not raise relevant issues in respect to the text. In the case where they happen to have access to the text, they should only be considered as 


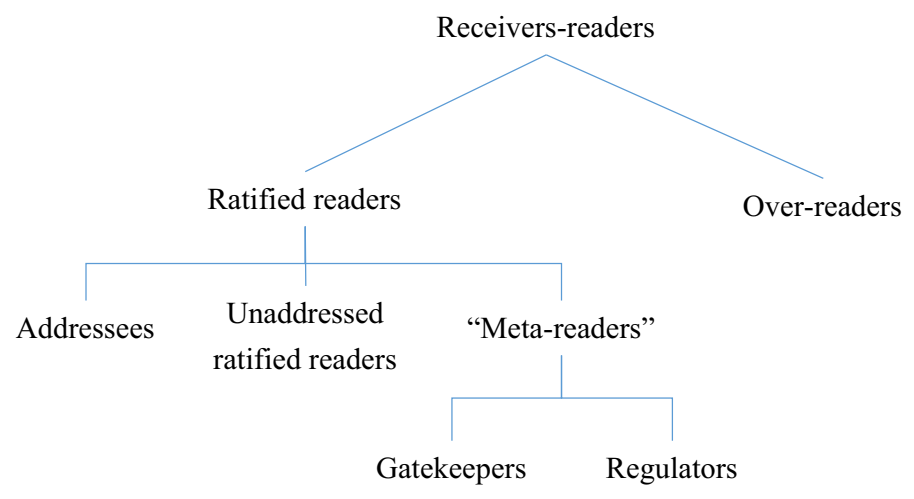

Fig. 1 Text stakeholders on the reception side (adapted from Mazzali-Lurati 2011)

important participants if they are in the position of modifying the exigence. The importance of over-readers varies according to the extent of text distribution: the more the text is made public, the less over-readers exist, because readers are more likely to be ratified.

Ratified readers can be of three types. The addressee is the one who is institutionally expected to be the main mediator of change: he/she has the power to modify the arguer's exigence more than any other participant. The main argumentative issue the writer has to resolve in the text coincides with a question raised by the addressee. Because of the fact that the text addresses him/her directly, the addressee expects to read something directly relevant for him/her, which could change his/her views. Indeed, as Rigotti and Cigada (2013) explain, a communicative act is always an invitation to involve the addressee and counts as an attempt to obtain a habit change. By designating the addressee with "you", the author acknowledges his/her same potential status of speaker/writer (Uspenskij 2008: 118-119). In an interpersonal dialogue, this means giving him/her the right to speak in a subsequent turn, while in asynchronous mass mediated communication, the addressee is the Aristotelian krites (van Rees and Rigotti 2011), whose reaction tends to coincide with the decision-making act, like voting or selling shares.

The unaddressed ratified readers are not directly addressed by the writer, who however should acknowledge their presence as relevant. The relevance of these readers depends on the fact that they could raise an important side issue, or, if persuaded on the main issue, they could represent a conduit for persuading the addressee (see the notion of secondary audience in van Eemeren 2010).

Gatekeepers and regulators are both considered as "meta-readers" because their stake focuses more directly on the text as the by-product of the writing process. They are expected to read the message without, however, entering into the merit of its content and argumentation. Particularly, gatekeepers are the ones who, thanks to their role in the activity type, decide whether or not to diffuse the text (or part of it) to a larger public. Regulators aim at establishing whether the text can be (legally speaking) published or not, given the legally established requirements disciplining its content, form and style. 


\subsection{Organizational Stakes and Argumentative Issues}

Following Mazzali-Lurati (2011), we refer to the different participants involved in the production and reception of an organizational message as the stakeholders of the text. By doing so, we take inspiration from the concept of corporate stakeholder, first introduced by management scholars and rapidly adopted within corporate communication studies, precisely to refer to the relevant publics that must be considered in preparing strategic communication interventions. ${ }^{18}$

Referring to audiences as text stakeholders emphasizes that the various groups of people involved in an organizational message hold a particular interest, which they expect the text will contribute to fulfilling. Corporate stakeholders are, in fact, all the persons and institutions that have an interest in some activity of the organization and, accordingly, "can affect or be affected by the achievement of the organization's objectives" (Freeman 1984: 46). The first to coin the term was the Stanford Research Institute, which in a 1963 memorandum defined corporate stakeholders as "those groups without whose support the organization would cease to exist" (see also Donaldson and Preston 1995: 72). Highlighting the mutual influence between the corporation and its stakeholders, Grunig and Repper define stakeholders as "people who are linked to an organization because they and the organization have consequences on each other" (1992: 125).

The fundamental idea behind this notion is that business corporations certainly need and have a duty toward shareholders (investors) but not only to them. Several actors, social groups and institutions should also be considered as relevant determinants of corporate success and as holders of an interest (the stake) which should not be ignored. Post, Preston and Sachs propose a model in which they include the following categories: investors (shareowners and lenders), customers and users, unions, regulatory authorities, joint venture partners and alliances, local communities and citizens, private organizations, supply chain associates, governments, employees (2002: 22). All these groups are interested, in different ways and to different degrees, in the success of the activity of the corporation. Starting from this interest, they engage themselves with the corporation, ${ }^{19}$ which has to be aware of their presence and their stake and establish priorities when necessary. According to Mitchell et al. (1997), the salience of a stakeholder, i.e. "the degree to which managers give priority to competing stakeholder claims" (p. 869) depends on three attributes, namely power (whether they can get the company to

\footnotetext{
18 The "corporate management" concept of stakeholder has been drawn on in a similar perspective in the field of web design and usability. Users, clients, decision makers, opinion makers, project managers, product managers, domain and content experts, content providers, as well as the development team (Perrone et al. 2005) are stakeholders of web sites and multimedia applications, because they all "have expectations, goals and interests connected to the implementation and success of the site" (Cantoni et al. 2003: 32; our translation).

19 Grunig and Hunt (1984) propose a linkage model to differentiate stakeholders according to how they are linked to the organization. Thus, they distinguish enabling, normative, functional and diffused linkages. These kinds of connection are presented as rather stable and largely situation-independent categories. In our terms, they describe a fixed interaction field, while leaving in the background the dynamic of field change by means of activity types, which in our approach is crucial in order to evaluate the role and importance of a stakeholder in a corporate message.
} 
do something), legitimacy (whether their presence is socially and normatively acceptable) and urgency (whether their claim requires immediate attention or not) (pp. 865-868).

The widespread diffusion of the stakeholder concept in management sciences (see Donaldson and Preston 1995) rapidly fertilized the field of corporate communication and public relations (Grunig and Repper 1992). Indeed, if there are other groups beyond shareholders that organizational leaders need or should take into account, then any strategic communication is such only if it is designed in a way that enhances the promotion of corporate image and reputation and the achievement of corporate objectives in front of all relevant stakeholders (Cornelissen 2014). In this perspective, stakeholders tend to be conceptualized as publics, thus highlighting the link that audiences have with corporate messages and not merely with the organization that produces the message (see Rawlins 2006). The stakeholder-public distinction is extremely important for one aspect that is crucial from an argumentative perspective on multiple audiences. While corporate stakeholders are generally linked to the interaction field (the organization as institution), publics arise from specific situations that create a problem (issue) for them and such a problem is recognized as important and urgent. This is the basis of the well-known situational theory of publics (Grunig 1997), which aims at establishing whether a public will actively seek information or not according to how each public is positioned toward the problem. This model takes into account the level of involvement, i.e. the personal connection with the problem; the problem recognition; the constraint recognition, i.e. the belief that something can be done to resolve the problem; and referent criteria, which are bound to previous experiences on which the assessment of the current problem is based (see Illia et al. 2013).

As in public relations studies, our notion of text stakeholder emphasizes the fact that the audiences of corporate messages do not simply have a generic linkage to the interaction field. Rather, they are part of an argumentative situation, in which they acknowledge the existence of one or more issues as relevant and important for themselves. In other words, publics are rhetorical audiences (Bitzer 1968) whose actions have the potential to modify the speaker/writer's exigence. Any rhetorical situation can be without hesitation defined as an argumentative situation when the exigence constitutes an issue (see Palmieri 2014) and removing this issue amounts to resolving the related difference of opinion in a reasonable and effective way (van Eemeren 2010). Unlike public relations studies, our argumentative perspective points out that the communicative behavior of audiences-publics cannot be reduced to that of information seekers. Audiences actually correspond to critical antagonists who (often implicitly) ask for reasons that justify a claim on the issue (van Eemeren and Grootendorst 2004). When an issue emerges in relation to one or more publics, reasons are demanded to decide whether or not to embrace the corporate standpoint on the issue. This is a fundamental aspect defining text stakeholders, which remains largely implicit in the public relations literature.

Even more importantly, our notion of text stakeholder specifies two crucial aspects: (1) stakeholders are represented within corporate messages by covering precise interactional roles which ideally should reflect their salience in the specific 
rhetorical situation to which the text responds. ${ }^{20}$ Within the text, their field-bound stake takes the form of an issue that is defined starting from the goals and commitments shared by the writer and the receivers of the message. A reader is a text stakeholder as he/she has an interest within the interaction field which makes him/her attentive towards the content of the text; he/she assumes an interaction role within the text through which his/her interest is considered; (2) each category of text stakeholder might be composite in that it comprises sub-groups with more specific starting points (see van Eemeren 2010), which accordingly raise different sub-issues (see Sect. 3.4).

Figure 2 recapitulates the theoretical reflections and distinctions made so far to illustrate the text stakeholder's conceptual framework. Any argumentative text is a sort of response to an argumentative situation defined around an issue, which entails the exigence triggering the situation. Dialectically speaking, the issue results in a difference of opinion between the arguer and one or more audiences who cast doubt on the arguer's standpoint or have an opposite view. The argumentative intervention the writer intends to design has to deal with a set of constraints bound to the institutionalized communicative activity type where the text is expected to be published. More specifically, such constraints derive from the interaction scheme and the interaction field constituting the communicative activity at hand. As explained in the preceding sections, text stakeholders arise precisely from the mapping of the scheme onto the field. A text stakeholder is a member of the interaction field (as such sharing some goals and having particular commitments), who (1) holds an interest towards the text in the form of an issue that the text is expected to resolve and (2) occupies a specific interactional role compatible with the interaction scheme activated by the text, which affects how the issue is represented and discussed.

\subsection{Reconsidering Multiple Audiences from a Text Stakeholder Perspective}

In this sub-section we propose revisiting with the notion of text stakeholder, the various concepts of non-single audience introduced in rhetorical and argumentative studies. Our proposal is summarized in the form of a matrix reproduced in Table 1. The matrix takes into consideration and combines two aspects, namely the presence (or not) of participants other than the addressee at the reception side and the composition of each category of participant.

Hence, we distinguish first of all a simple audience when there is no receiver other than the addressee, from argumentative situations with a complex audience, which also involves other categories of text stakeholder (e.g. unaddressed ratified readers). To grasp the difference, compare for example an email with or without anyone in cc. Secondly, we consider the composition of each participant type in order to distinguish between homogeneous and heterogeneous audiences. An

\footnotetext{
${ }^{20}$ Other studies in the field of business communication have underlined the strict relationship existing between the different stakes that different categories of stakeholders have in a corporation and the different form the dialogue between stakeholders and corporation assumes (Johansen and Nielsen 2011). However, these studies remain bound to the corporate management view of stakeholders as actors related to the organization and its internal and external image (see Illia and Lurati 2006) and do not correspond to different roles in communicative terms.
} 


\section{WRITER - TEXT}

(containing argumentative strategies)

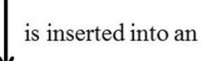

Argumentative situation

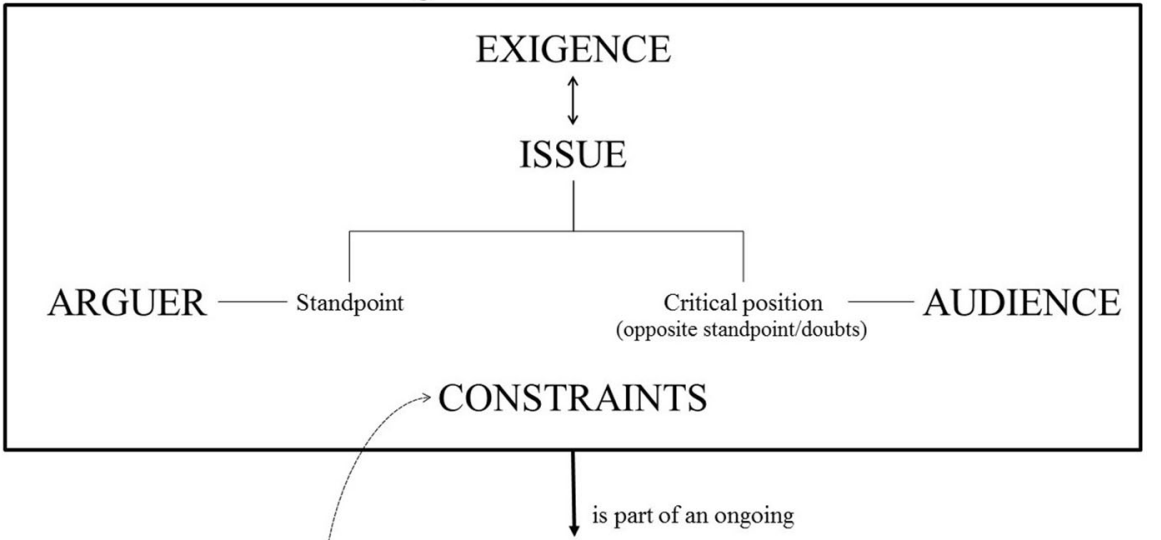

\section{Communicative activity type}

$\begin{gathered}\text { Animator, Author, } \\ \text { Principal }\end{gathered}$
$\begin{gathered}\text { Chairman, CEO, } \\ \text { media officers, IR } \\ \text { head, assistants, etc. }\end{gathered}$
INTERACTION
(Interactional roles)
Text participants
FIELD
(Stakes, interest, issue)
Corporate stakeholders

Addressee, Unaddressed ratified reader, Over-reader, Gatekeeper, Regulator

Shareholders, employees, clients, governmental authorities, media, etc.

\section{TEXT STAKEHOLDERS}

Fig. 2 Text stakeholders in argumentative situations

audience is homogenous if it is composed of one person or of a group of people who share the same goals and commitments within the interaction field and thus have similar starting points. If the members of one type of text stakeholders have partially different starting points, which lead them to raise different issues or sub-issues, we speak of heterogeneous audience ${ }^{21}$ (comparable to van Eemeren's mixed audience).

\footnotetext{
${ }^{21}$ Heterogeneous audience is a concept that is also used by Zarefsky (2008) in order to characterize political argumentation and the constraints that this context imposes on argumentation. Zarefsky remarks that political argumentation is shaped by the presence of "heterogeneous audiences holding inconsistent standpoints" (p. 322).
} 
Table 1 Types of multiple audiences

\begin{tabular}{|c|c|c|}
\hline & $\begin{array}{c}\text { Simple } \\
\text { addressee is the only } \\
\text { participant }\end{array}$ & $\begin{array}{c}\text { Complex } \\
\text { = more than one participant type }\end{array}$ \\
$\begin{array}{c}\text { Homogeneous } \\
\text { the members of each } \\
\text { participant type have the same } \\
\text { starting points (goals and/or } \\
\text { commitments) }\end{array}$ & SINGLE AUDIENCE & $\begin{array}{c}\text { MULTIPLE AUDIENCE } \\
\text { of non-composite addressee }+ \\
\text { other non-composite participants }\end{array}$ \\
$\begin{array}{c}\text { Heterogeneous } \\
\text { the members of each } \\
\text { participant type have different } \\
\text { starting points (goals and/or } \\
\text { commitments) }\end{array}$ & $\begin{array}{c}\text { MULTIPLE AUDIENCE } \\
\text { of composite addressees }\end{array}$ & $\begin{array}{c}\text { MULTIPLE AUDIENCE } \\
\text { of more participant types at least } \\
\text { one composite }\end{array}$ \\
\hline
\end{tabular}

As the matrix shows, three types of multiple audience can be distinguished: a complex audience where all text stakeholders are homogenous; a complex audience where at least one text stakeholder is composite; and a simple audience where the addressee is composite. In all three cases, the arguer is confronted with multiple issues and/or sub-issues which can be more or less compatible with each other and can be viewed by the arguer as having different priorities, ${ }^{22}$ thereby determining different argumentative strategies.

\section{The Aer Lingus Case: Analysis and Discussion}

In this section, we come back to the Ryanair-Aer Lingus case and systematically apply the text stakeholder framework for the audience analysis of one crucial speech event: the Aer Lingus defense document (or defense circular) against Ryanair's second takeover attempt in 2008. First, we characterize the communicative activity type into which this text is inserted and define the precise argumentative situation which the text refers to (Sect. 4.1); on the basis of this contextual knowledge, we identify and describe the different audiences-readers of this text (Sect. 4.2).

\subsection{Takeover Defense Document: Interaction Scheme, Interaction Field}

The Aer Lingus defense circular we are considering in our analysis was published on December 22nd, 2008, one week after Ryanair had released its offer document (December 15th).

Takeover defense documents are published by the Board of directors of a listed company that has become the target of a hostile takeover bid, i.e. an offer to buy one company's shares, which is contested by the other company's directors. This text type is inherently argumentative as the main pragmatic aim of the writer is to provide shareholders with reasons that convincingly justify the rejection of the offer

\footnotetext{
22 At this level, the arguer might determine that one audience is primary while another one is secondary (see van Eemeren 2010:109) and adapt his/her argumentation according to the different levels of importance attributed to various text stakeholders.
} 
(see Palmieri 2008). As it follows the publication of the offer document by the bidder, the defense circular typically contains both pro-arguments justifying the standpoint that the offer should be rejected and counter-arguments refuting the reasons previously advanced by the bidder to support the offer's acceptance (Brennan et al. 2010; Palmieri 2012a, 2014).

The defense document represents, in fact, one crucial episode of a series of documents and announcements that the bidder and the target directors publish in the course of a hostile bid. Indeed, more than twenty texts-including announcements, letters, offer documentations-were published by one of the two companies between December 1st, 2008 (when the Aer Lingus directors announced that they had been notified of an offer by Ryanair) and January 28th, 2009 (when Ryanair announced it had withdrawn its offer). The Aer Lingus' defense document appeared after several other texts had been published, particularly after Ryanair released its offer document (on December 15th). ${ }^{23}$

Taken together, these publications give shape to a complex (argumentative) activity type that can be referred to as a takeover battle. We call this activity type 'complex' because it arises from the combination of several interconnected speech events, all applying an interaction scheme on their own. For example, the offer document activates the interaction scheme of proposal to a collective decision maker, where Ryanair (the bidder) takes the role of proposal-maker and the shareholders of Aer-Lingus (the target) take the role of collective decision-maker. By contrast, the defense document activates the interaction scheme of advice to a collective decision-maker, where the role of advisor is filled by the Aer Lingus Board while, obviously, the collective decision-maker is again the Aer Lingus shareholders. Other communicative events (texts) characterizing the offer period implement either one of these two schemes (e.g. a second offer document) or other interaction schemes (e.g. a press release).

The interaction scheme 'advice to a collective decision-maker' is a particular case of the interaction scheme of advice (or recommendation), which involves the roles of advisor and advisee. The advisee has to make a practical decision and relies on the advisor whose role is that of recommending the most prudent course of action. Independently from the interaction field where advice is given, the advisor is expected to comply with some prerequisites, which broadly coincide with the felicity conditions of the speech act 'advising': he/she is expected to have information, knowledge and wisdom, to be expert in the domain of the decision at issue, to be reliable and benevolent regarding the goals and desires of the advisee. When the advisee is a collective decision-maker (e.g. an assembly, citizens, etc.) rather than an individual one (e.g. a bank client), the eventual decision normally arises from the collective action-voting, selling, etc.-of a qualified majority and counts as the action chosen by the collective subject. In other words, every member of the collective subject accepts de jure that the action that "wins" the discussion is the action that has to be realized by the collective subject. Thus, if the majority of

\footnotetext{
23 The whole series of published documents can be easily retrieved from the website of Financial Express Investegate, a secondary information provider which publishes all announcements from UK quoted companies. url: http://www.investegate.co.uk/.
} 
the target shareholders agree to accept the bid, then all shareholders (including those who have not agreed to sell) sell their shares to the bidder.

Because the defense document implements this interaction scheme onto a public interaction field (see below), other interactional roles emerge besides the advisor and the advisee, which are covered by all those members of the interaction field who can be reasonably expected to read the corporate text. The format of the interaction scheme refers to them generically as third parties (see Clark and Carlson 1982), as their precise participation role can only be defined after considering the whole activity type, specifically the interaction field where the scheme is implemented.

As explained by Palmieri (2014: 65-66), the interaction field where takeover bids occur is the target company, i.e. the publicly-listed stock corporation whose shares become the target of a bid by another company. A target company-Aer Lingus in our case-actually entails a complex of institutional venues (see Aakhus and Lewinski 2014), which become involved in the takeover bid. Figure 3 schematically represents them by also indicating the main institutional actors that are found within each venue.

Because takeover bids aim at acquiring the shares of a listed company, a first component of the interaction field is the stock market where the target shares are listed, in our case the Irish stock market. The primary shared goal of the stock market is to favor sound investments by facilitating, on the one side, the allocation of capital by investors-shareholders and, on the other side, the raising of capital by business enterprises (see Barone-Adesi 2002). Besides the category of investors, which includes Aer Lingus shareholders, financial analysts and journalists also play a relevant function. These information intermediaries (see Healy and Palepu 2001) scrutinize corporate disclosures and issue opinions, comments, or recommendations that may help investors support their investment decisions, such as the decision whether or not to sell their shares to a bidder. A similar role is played by financial advisors working for a bank (financial intermediaries), who might need to assess an

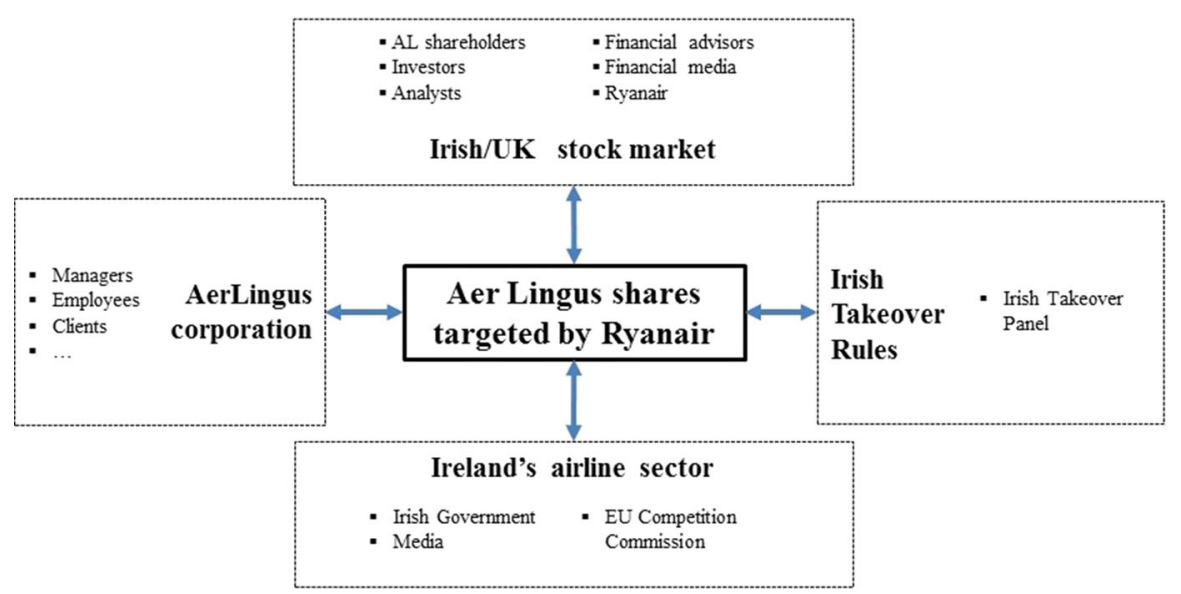

Fig. 3 Aer Lingus defense document: interaction field and stakeholders 
offer in order to personally advise their client-shareholder (Palmieri and Palmieri 2012). The venue of the Irish stock market in the Aer Lingus case also includes Ryanair whose offer represents an intervention into this social reality aimed at substantially changing such an institutional context (i.e. transferring the full control of the company from Aer Lingus existing shareholders to Ryanair).

However, it is important to remark that the context that a takeover bid aims at changing is already modified by the mere announcement of the offer, independently of whether such an offer will eventually be accepted or not. As soon as the intention to make an offer (or even a possible offer) is disclosed, new institutional commitments come into being in the form of specific takeover rules (see HaanKamminga 2006). These rules, which are administered by the Irish Takeover Panel, have been designed with the purpose of enabling shareholders to receive enough information to reach a properly informed decision as to whether to accept or reject the offer (see General Principles, http://irishtakeoverpanel.ie/rules/takeover-rules).

By "updating" the set of commitments that market interagents share in the context of their ordinary activities, takeover rules impose further institutional constraints on argumentation (see Palmieri 2014: 74-84). Particularly, Irish Takeover Rules (to which both Ryanair and Aer Lingus were subject) request the bidder to publish an offer document containing relevant financial and non-financial information on the offer, including the reasons motivating it; while the target Board has to publish a reasoned opinion on the offer, i.e. they have to declare their standpoint in relation to the acceptability of the offer and state the arguments that support this standpoint (Palmieri 2014: 74-81). In the context of hostile bids, the target reasoned opinion takes the form of the so-called defense circular or document.

Since takeover offers are aimed at acquiring control of a company with the eventual purpose of transforming it more or less substantially, the interaction field comprises the target corporation as a whole organization which also pursues the interests of non-financial stakeholders, such as clients, employees and the executive managers themselves.

Furthermore, takeovers often bring consequences at an industrial level. This is especially the case for horizontal mergers, i.e. those combinations involving two firms that belong to and compete within the same industrial sector. In such cases, takeover deals fall under the close scrutiny of antitrust authorities-the EU Competition Commission in the Ryanair-Aer Lingus case-who want to prevent possible market monopolies which would damage consumers (see Trautwein 1990). The importance of the airline sector for the quality of the transportation services of a country makes the Irish people and the Government representing them salient stakeholders in the activity of a national flag carrier such as Aer Lingus. It is not by chance that the Irish Government retained a financial stake in Aer Lingus even after the 2006 Initial Public Offering, by which the company was sold on the stock market.

As explained in Sect. 3.1, organizational texts intervene in a context by responding to a precise situation, the latter corresponding to a particular status of the interaction field concerned. The Aer Lingus defense document, (as with all target defense documents in general), was published after the bidder (Ryanair) had 


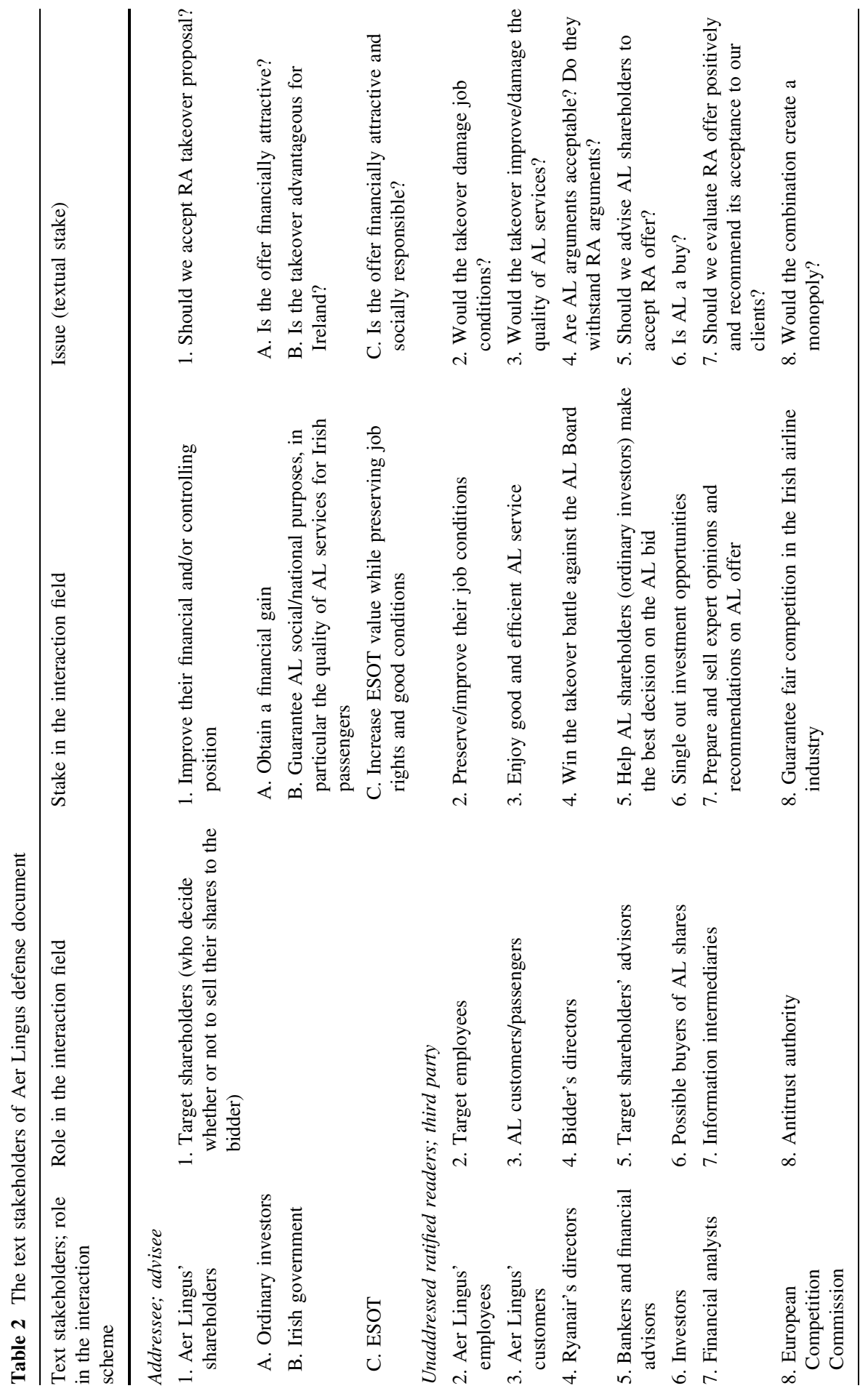




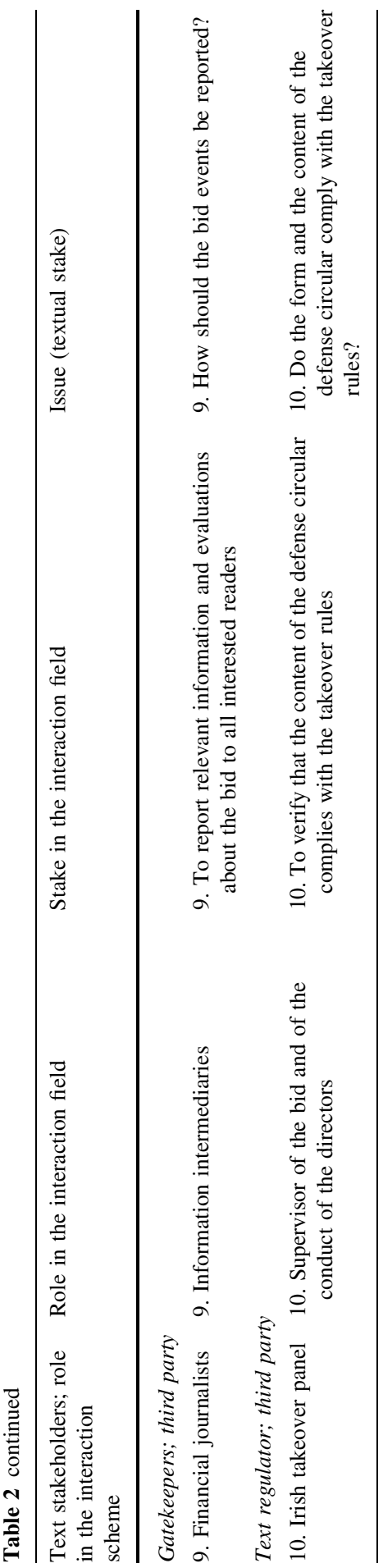


disclosed its offer document, which in turn was preceded by other announcements where argumentation in favor of and against the offer had already taken place. The emergence of a hostile offer, which becomes official with the publication of the offer document, creates the rhetorical exigence for the defense document: the target Board is urged to react in order to prevent the realization of the takeover which the bidder aims at achieving with the offer document. The main argumentative issue that is entailed in this exigence is whether Ryanair's proposed takeover of Aer Lingus should be approved or not. For the directors and managers of Aer Lingus, resolving this issue in their favor-i.e. persuading the relevant audiences that Ryanair's offer should be rejected-is a necessary instrument for removing their exigence.

\subsection{Audience Structure}

The mapping of the scheme of public advice to a collective decision-maker onto this particular field assigns the role of advisor to the Board of Aer Lingus, the role of collective advisee to the Aer Lingus shareholders and the role of third party to the other actors of the complex field explained above (see Fig. 3). All these actors play a role in the communicative activity type activated by the document and have an interest in the content of the defense circular. Given the different nature of their respective interest towards the defense circular and the different roles they play in the takeover defense activity type, all these actors should be considered as different types of text stakeholders. Each of them looks at the offer by raising an issue which holds a certain degree of influence on the exigence and the corresponding writer's goal.

Table 2 provides a list of the text stakeholders we have identified for the Aer Lingus defense document. They have been divided into four categories, depending on whether they are addressees, ratified readers, gatekeepers or text regulators. For each of them, we specify the role and stake they have in the interaction field and the corresponding argumentative issue they raise.

\subsubsection{Addressees}

The addressee of this text coincides with the Aer Lingus shareholders. The writer address them explicitly both in the salutation of the Chairman's letter ("Dear Shareholders") and in the legal notices on p. 2, which refer to them as "you" (e.g. "If you have sold or otherwise transferred all of your Aer Lingus Shares..."). They play the role of advisee in the activated interaction scheme as they rely on the defense circular to construct their decision. This decision-making power makes them crucial mediators of change and, thus, salient text stakeholders.

In general, corporate shareholders are defined by two main interests: financial profit and corporate control, either in view of ensuring their financial gain or in view of ensuring that the company will pursue one or more of the social purposes it is expected to achieve. The ownership of a listed corporation often includes subgroups of shareholders who might differ in their concern for profit and control. This was certainly the case for Aer Lingus at the time of Ryanair's offer. As the 
table shows, Aer Lingus shareholders constitute a composite audience as different institutional actors hold shares by pursuing partially different goals and having partially different starting points. We identify and distinguish in particular three categories of Aer Lingus shareholders, corresponding to three different text stakeholders of the defense document. First, there are ordinary investors, whose primary goal is to increase the value of their wealth invested in Aer Lingus. In turn, this category can be further subdivided into more specific subcategories such as short-term and long-term shareholders or institutional and retail shareholders. Secondly, the Irish government was holding a significant number of the shares of Aer Lingus, which was indeed a state-owned company until 2006. In considering the bid, the Irish government attributes particular importance to the quality of the airline services for the Ireland's citizens, i.e. the main customers of Aer Lingus. One of the strategic goals of a government is, in fact, that of ensuring the existence of an efficient and effective airline service. Thirdly, $15 \%$ of the Aer Lingus shares were owned by the employees through the Employees Share Ownership Trust. Employeeshareholders evidently are especially concerned about their employment conditions and, accordingly, assess the desirability of Ryanair's proposal for its impact on employment.

All these stakes entail sub-issues which explain why the defense document contains several non-financial arguments (e.g. "Aer Lingus offers consumers real choice"; "The merger will be anti-competitive"), which in other situations could be less important or wholly meaningless for shareholders, if compared to typical financial reasons (e.g. the inadequacy of the offer price). ${ }^{24}$

\subsubsection{Unaddressed Ratified Readers}

Although Ryanair was holding a huge proportion of Aer Lingus' shares (29\%), the defense circular does not consider it as an actual addressee. Ryanair is repeatedly and always mentioned as the (hostile) bidder; never as one of the largest Aer Lingus shareholders who needs to be persuaded. In this specific argumentative interaction, Ryanair is the author of the offer document, and, as such is the trigger for the exigence that gave birth to the defense document. Indeed, its textual stake is fundamentally different from that of the other components of Aer Lingus' shareholding: Ryanair already decided what to do with its shares and does not need Aer Lingus' advice; by contrast, it is interested in supervising Aer Lingus' arguments against the bid in view of preparing possible refutations. Therefore, in terms of our text stakeholder framework, Ryanair's Board of directors is not an addressee of the defense document written by Aer Lingus, but an unaddressed ratified reader.

Not all shareholders make their decisions by themselves. Many of them rely on further advice by bankers and other independent financial advisers. Bankers and financial advisers do not make the decision about Ryanair's offer, but advise

\footnotetext{
24 As shown by Palmieri (2014), the argumentation of defense documents typically does not contain nonfinancial themes, suggesting that the target directors are framing their main audience as a purely financial investor who is neutral to non-financial issues.
} 
shareholders during a separate, though interconnected, argumentative activity type entailed by takeover bids. In such an activity, they play the role of advisor, but in the specific context of the defense circular, they are third parties, whose stake is to evaluate the arguments of Aer Lingus' Board from the perspective of the shareholders' stake (profit and control). Their status of ratified readers is confirmed in the legal notices of the document where the Aer Lingus Board invites shareholders to involve these actors in their decision-making. ${ }^{25}$

Non-shareholder employees are also unaddressed ratified readers. They cannot make a decision in respect to the bid, but they are affected by it and have a clear stake: will the takeover damage employment conditions? Employees are explicitly ratified by takeover rules, which also force the target directors to consider, in their reasoned opinion, the effects of the proposed bid on employment (Takeover Rules, Rule 25.1) and to ensure that the defense circular is made available to employees' representatives. Showing awareness of this stake, the Aer Lingus directors point out that "our employees have cooperatively agreed significant changes in work practices and reductions in costs which will allow the airline to grow further and will underpin both employment and profitability in the future" (p. 3) and argue whether "[it is] credible that Ryanair is really going to allow Aer Lingus to operate separately, with the existing management team, employees and business" (p. 4).

While their interest is represented by the Irish government and the antitrustauthorities, Aer Lingus customers (consumers) must be included among unaddressed ratified readers. Their stake gives rise to an issue ("would the takeover improve or damage the quality of Aer Lingus services?") which entails another issue raised by the European Competition Commission: would a Ryanair-Aer Lingus merger create a monopoly? The Commission is not an addressee because it cannot modify the bidder's exigence by rejecting/accepting the financial offer the document refers to. However, it has institutional power to prohibit the merger that would result from an accepted bid. The Board of directors appears to be fully aware of this and, accordingly, it is attentive in adequately formulating arguments that are relevant from an antitrust perspective too. On pages 21-23, the Aer Lingus Board argues for the risks of monopoly in a way that appears to be meant to convince shareholders (both private and public) that the takeover will be blocked by the Commission. It is a sort of pre-formulated argumentation that seems to be tailored to the Commission, because the reasons, which are stated, should lead the Commission to forbid the merger.

As events taking place in the stock market, takeover bids naturally involve several financial actors who might be interested in how the Aer Lingus case develops. These include investors other than Aer Lingus' shareholders who might consider buying Aer Lingus shares. A takeover bid, in fact, attracts investors' attention towards the target company's short-term and long-term prospects. Aer Lingus' directors know that the soundness and persuasiveness of their arguments supporting the company's standalone case have an influence on the decision of

\footnotetext{
25 "This document is important and requires your immediate attention. When considering what action you should take, you are recommended to obtain advice from a stockbroker, bank manager, solicitor, accountant, fund manager, or other independent financial adviser..." (p. 2).
} 
potential buyers as well as on their image, reputation and credibility within the whole market. The numerous elements mentioned to defend the claim that "Aer Lingus has a vibrant independent future" (p. 1) seem to be also indirectly addressed also to these ratified audiences.

Finally, the influential presence of security analysts should not be underestimated. During a takeover, their institutional mission of assessing the value of a company and recommending investors to buy or sell shares is accomplished by carefully examining the texts that the bidder and the target directors disclose (see Palmieri and Palmieri 2012). Often the companies involved in a bid organize a conference call in which many analysts participate by asking critical questions to managers and directors and by engaging in argumentative dialogues with them (see Palmieri et al. 2015). Analysts may amplify corporate arguments by reporting or reformulating them in their own communication as well as criticizing and refuting them. A sign that Aer Lingus directors were aware of the presence of analysts and considered it in their argumentation is, for instance, the use of Peer Trading Valuation to show the inadequacy of the offer price. Indeed, this technique of valuation is one of the typical methods adopted by financial analysts in their own analyses and recommendations (Fernandez 2001).

\subsubsection{Gatekeepers}

Financial media are, like analysts, information intermediaries in the stock market. They also read and assess corporate statements and use them to write their own stories, opinions and commentaries in which they often report analysts' evaluations. In this respect, journalists act as gatekeepers for both the arguments published by the companies in press releases and in other documents and the arguments expressed by analysts. Similarly to financial analysts, they are interested in understanding the pros and cons of the takeover, but from the general perspective of keeping public opinion adequately informed rather than providing an expert opinion on the transaction.

Even though the defense document is sent directly to the shareholders and is made available on the corporate website, journalists may still act as gatekeepers by influencing the reader's awareness of the document. By reporting or commenting on specific passages of the corporate texts, journalists may draw other audiences' attention to certain passages instead of others. Generally speaking, the choice and formulation of the arguments from the perspective of both the shareholders and the financial analysts also responds indirectly to their interest in the text. Moreover, the presence of news pre-formulated elements in the text (such as quotations) can also be seen (but not exclusively) as a strategic move towards this category of text stakeholders.

\subsubsection{Text Regulators}

The role of text regulator is covered by the Takeover Panel, which has the institutional duty of supervising all corporate messages published during the offer period to make sure they comply with the standards defined in the Takeover Rules. 
These include not only the type of information that must be disclosed but also the manner in which information is presented and the time at which it is made public.

\section{Conclusions}

Strategic communication by profit and non-profit organizations typically involves a multiple audience. From an argumentative perspective, this means that the design of arguments should account for a situation in which several critical antagonists read the corporate message and raise different issues and sub-issues. This paper proposes the notion of text stakeholder as a theoretical framework supporting the identification and distinction of different readers, which can be helpful both for real organizational writers and for external discourse analysts.

This notion was first suggested by Mazzali-Lurati in prior works where she proposed distinguishing different text participants according to the interest they bear toward the text and to combine the management concept of stakeholder with the concept of participation role in linguistic studies. What we propose in this paper is a refined elaboration of Mazzali-Lurati's notion of text stakeholder, where the different theoretical constructs underpinning this notion have been integrated in a more systematic way. In particular, we have referred to Rigotti and Rocci's model of communication context to distinguish between the interaction field and the interaction scheme components of an activity type so that it becomes clearer how the rhetorical situation involves several participants and what rhetorical role each of them holds. Moreover, the scope of this paper is on the reception side of the message, as our aim is to characterize the different audiences that strategic arguers must deal with in their texts. We thus show how conceptualizing audiences as text stakeholders relates to existing categorizations of multiple audiences, such as primary and secondary or homogenous and heterogeneous audiences. Moreover, and more importantly, we have highlighted the crucial implications of this notion at the argumentative level. The textual stake of an audience, which derives from its role in the scheme and field-based activity type, corresponds to an argumentative issue, which the arguer needs to account for in order to make the text effective in its pragmatic aim.

In order to illustrate how the notion of text stakeholder can guide the audience analysis of a real case of argumentative text, we examined one of the defense documents prepared by Aer Lingus to fend off a hostile takeover bid. The characterization of the defense document as a communicative activity type by means of Rigotti and Rocci's model of context, allowed us to single out all relevant participants, their stake in the situation to which the corporate text reacts and the specific interactional role they play within the text. We maintain that by applying the text stakeholder notion to audience analysis it is possible to better explain certain strategic choices made by the arguer. In this regard, we believe that the illustrative example of the Aer Lingus defense document has demonstrated the advantages of our notion. For instance, by identifying the European Competition Commission and the financial analysts as unaddressed ratified participants and by specifying the peculiar stake they hold, we could better account for some of the Aer 
Lingus topical and presentation choices. However, our main goal in this paper was to develop a theoretical notion rather than applying it to the concrete audience analysis of real argumentative texts. This would be, of course, the logical continuation of the project initiated in this essay. Furthermore, it would be particularly interesting to investigate how new media such as blogs and tweets are used by companies to reach several audiences of stakeholders.

Our paper also adds to the important work on stakeholder analysis done within corporate communication studies. Public relations and corporate communication scholars tend to emphasize the presence of different audiences of stakeholders and to identify them against different social groups, while the interactional roles mapping organizational roles are put aside. Our integrated notion of text stakeholder, which combines the interaction scheme and interaction field components and imports Goffman's and others' reflections on participation roles into a stakeholder perspective, fills a gap that is rather common in these approaches.

In this paper the different degrees of salience held by each text stakeholder has not been addressed. We have not discussed which factors might intervene in defining which issues are more important and urgent, and also what relationships may exist between different issues. The necessity to better understand these aspects calls for further research examining real argumentative texts starting from an audience analysis in the text stakeholder framework.

Acknowledgments We wish to thank Jenny Stevens-Prada for grammar and spelling revision. Also, we are very grateful to Mark Aakhus and Andrea Rocci for their precious comments on an earlier version of the manuscript. It goes without saying that responsibility for the final version of the article is fully ours.

Open Access This article is distributed under the terms of the Creative Commons Attribution 4.0 International License (http://creativecommons.org/licenses/by/4.0/), which permits unrestricted use, distribution, and reproduction in any medium, provided you give appropriate credit to the original author(s) and the source, provide a link to the Creative Commons license, and indicate if changes were made.

\section{References}

Aakhus, M., and M. Lewinski. 2014. Toward polylogical analysis of argumentation: Analyzing disagreement space in the public deliberation about fracking. In 2014 ISSA conference, Amsterdam.

Aakhus, M., and M. Lewinski. 2011. Argument analysis in large-scale deliberation. In Keeping in touch with Pragma-dialectics, ed. E. Feteris, B. Garssen, and F. Snoeck Henkemans, 165-184. Amsterdam: John Benjamins.

Aakhus, M., and A. Vasilyeva. 2008. Managing disagreement space in multiparty deliberation. In Controversy and confrontation: Relating controversy analysis with argumentation theory, ed. F.H. van Eemeren, and B. Garssen, 197-214. Amsterdam: John Benjamins.

Aer Lingus. 2008. Reject Ryan air offer. Defense Document 22(12): 2008.

Bakhtin, M. 1982. The dialogic imagination. Trans. C. Emerson \& M. Holquist. Austin: University of Texas Press.

Barone-Adesi, G. 2002. The role of inside information. Financial disclosure and value creation. In Business journalism, corporate communications, and newsroom management, ed. S. Russ-Mohl, and S. Fengler, 63-68. Lugano: USI.

Bell, A. 1984. Language style as audience design. Language in Society 13(2): 145-204.

Bell, A. 1991. The language of news media. Oxford: Blackwell. 
Benoit, W.L., and J.M. D'Agostine. 1994. The case of the midnight judges" and multiple audience discourse: Chief justice Marshall and Marbury V. Madison. The Southern Communication Journal 59(2): 89-96.

Bitzer, L. 1968. The rhetorical situation. Philosophy and Rhetoric 1: 1-14.

Bitzer, L. 1978. Rhetoric and public knowledge. In Rhetoric, philosophy, and literature: An exploration, ed. D.M. Burks. West Lafayette, IN: Purdue University Press.

Bitzer, L. 1980. Functional communication: A situational perspective. In Rhetoric in transition: Studies in the nature and uses of rhetoric, ed. E. White, 21-38. University Park/London: Pennsylvanian State University Press.

Brennan, N.M. 1999. Voluntary disclosure of profit forecasts by target companies in takeover bids. Journal of Business Finance \& Accounting 26(7/8): 883-917.

Brennan, N.M., C. Daly, and C. Harrington. 2010. Rhetoric, argument and impression management in hostile takeover defence documents. British Accounting Review 42(4): 253-268.

Caplan, H. 1954. [Cicero]. Rhetorica ad Herennium (Loeb classical library). Harvard: Harvard University Press.

Cicero. 1962. Brutus/Orator, ed. G.L. Hendrickson. With an English translation by H.M. Hubbell. London: Heinemann [u.a.].

Cicero. 1942. De Oratore in two volumes. With an English translation by H. Rackham. London: William Heinemann.

Clark, H.H. 1992. Arenas of language use. Chicago/London: University of Chicago Press/Center for the Study of Language and Information.

Clark, H.H., and T.B. Carlson. 1982. Hearers and Speech Acts, Language 58(2):332-373. Reprinted in: H.H. Clark (1992) Arenas of language use. Chicago: University of Chicago Press; London: Center for the study of language and information.

Cooke, T.E., R.G. Luther, and B.R. Pears. 1998. The information content of defence documents in UK hostile takeover bids. Journal of Business Finance \& Accounting 25(1-2): 115-143.

Cornelissen, J.P. 2014. Corporate Communication: A Guide to Theory and Practice. 4th ed. London: Sage.

Cross, G. 1994. Collaboration and conflict: A contextual exploration of group writing and positive emphasis. Cresskill, NJ: Hampton Press.

Cross, G. 2001. Forming the collective mind: A contextual exploration of large-scale collaborative writing in industry. Cresskill, NJ: Hampton Press.

De Saussure, F. 1995. Cours de linguistique générale. Paris: Payot \& Rivage.

Duncan, H.D. 1962. Communication and social order. New Brunswick/Oxford: Transaction Books.

Donaldson, T., and Preston, L. E. 1995. The stakeholder theory of the corporation: Concepts, evidence, and implications. Academy of management Review, 20(1): 65-91.

Dynel, M. 2010. Not hearing things-Hearer/listener categories in polylogues, mediAzioni, 9. http:// mediazioni.sitlec.unibo.it.

Dynel, M. 2011. Revisiting Goffman's postulates on participant statuses in verbal interaction. Language and Linguistics Compass 5(7): 454-465.

Ede, L. 1984. Audience: An introduction to research. College Composition and Communication 35(2): $140-154$.

Ede, L., and A. Lunsford. 1984. Audience addressed/audience invoked: The role of audience in composition theory and pedagogy. College Composition and Communication 35(2): 155-171.

Eisenhardt, K.M. 1989. Agency theory: An assessment and review. Academy of Management Review 14(1): 57-74.

Fernandez, P. 2001. Valuation using multiples: How do analysts reach their conclusions? Working Paper, IESE Business School.

Flower, L. 1981. Problem-solving strategies for writing. San Diego: Harcourt Brace Jovanovich Publishers.

Freeman, R.E. 1984. Strategic management: A stakeholder approach. Boston: Pitman.

Goffman, E. 1981. Forms of talk. Philadelphia: University of Pennsylvania Press.

Greco Morasso, S. 2011. Argumentation in dispute mediation. A reasonable way to handle conflict. Amsterdam: John Benjamins.

Grunig, J.E. 1997. A situational theory of publics: Conceptual history, recent challenges and new research. In Public relations research: An international perspective, eds. D. Moss, T. MacManus and D. Vercic, 3-46. London: International Thomson Business Press. 
Grunig, J.E., and Hunt, T. 1984. Managing Public Relations. Fort Worth, TX: Holt, Rinehart and Winston.

Grunig, J.E., and F.C. Repper. 1992. Strategic management, publics, and issues. In Excellence in public relations and communication management: Contributions to effective organizations, ed. J.E. Grunig, 117-157. Hillsdale: Lawrence Erlbaum Associates, Inc.

Haan-Kamminga, A. 2006. Supervision on takeover bids: A comparison of regulatory arrangements. Deventer: Kluwer.

Hamblin, C.L. 1970. Fallacies. London: Methuen.

Healy, P.M., and K.G. Palepu. 2001. Information asymmetry, corporate disclosure, and the capital markets: A review of the empirical disclosure literature. Journal of Accounting and Economics 31: 405-440.

Huettman, E. 1996. Writing for multiple audiences: An examination of audience concerns in a hospitality consulting firm. The Journal of Business Communication 33(3): 257-273.

Illia, L., F. Lurati, and R. Casalaz. 2013. Situational theory of publics: Exploring a cultural ethnocentric bias. Journal of Public Relations Research 25(2): 93-122.

Illia, L., and F. Lurati. 2006. Stakeholder perspectives on organizational identity: Searching for a relationship approach. Corporate Reputation Review 8(4): 293-304.

Jacobs, S. 2000. Rhetoric and dialectic from the standpoint of normative pragmatics. Argumentation 14(3): 261-286.

Jacobs, S. 2009. Nonfallacious rhetorical design in argumentation. In Pondering on Problems of Argumentation, ed. F.H. van Eemeren and B. Garssen, 55-78. Dordrecht: Springer.

Jacobs, S., and S. Jackson. 2006. Derailments of argumentation: It takes two to tango. In Considering pragma-dialectics, ed. P. Houtlosser, and A. van Rees, 121-134. New York/London: Routledge.

Jakobson, R. 1968. Closing statement: Linguistics and poetics. In Style in language, ed. T.A. Sebeok, 349-377. Cambridge, MA: Massachusetts Institute of Technology Press.

Jameson, D.A. 2000. Telling the investment story: A narrative analysis of shareholder reports. Journal of Business Communication 37(1): 7-38.

Jasinski, J. 2001. Sourcebook on rhetoric: Key concepts in contemporary rhetorical studies. Thousand Oaks, CA: Sage.

Johansen, T.S., and A.E. Nielsen. 2011. Strategic stakeholder dialogues: A discursive perspective on relationship building. Corporate Communications: An International Journal 16(3): 204-217.

Kerbrat-Orecchioni, C. 2004. Introducing polylogue. Journal of Pragmatics 36: 1-24.

Levinson, S.C. 1979/1992. Activity types and language. Linguistics 17. Reprinted in: P. Drew and J. Heritage (Eds): Talk at work. Cambridge: Cambridge University Press, 66-100.

Levinson, S.C. 1988. Putting linguistics on a proper footing: Explorations in Goffman's concepts of participation. In Erving Goffman: Exploring the interaction order, ed. P. Drew, and A. Wootton, 161-227. Cambridge: Polity Press.

Lewinski, M. 2010. Internet political discussion forums as an argumentative activity type: A pragmadialectical analysis of online forms of strategic maneuvering in reacting critically. Ph.D. dissertation. Amsterdam: Rozenberg Publishers.

Lewinski, M., and M. Aakhus. 2014. Argumentative polylogues in a dialectical framework: A methodological inquiry. Argumentation 28: 161-185.

Mazzali-Lurati, S. 2011. Generi e portatori di interesse: Due nozioni-chiave per la scrittura nelle organizzazioni. Cultura e Comunicazione 04: 12-18.

Mazzali-Lurati, S., and C. Pollaroli. 2013. Stakeholders in promotional genres. A rhetorical perspective on marketing communication. In What do we know about the world? Rhetorical and argumentative perspectives, ed. G. Kišiček, and I.Ž. Žagar, 365-389. Ljubljana: Digital Library of Slovenia \& Windsor Studies in Argumentation.

McCawley, J. 1999. Participant roles, frames, and speech acts. Linguistics and Philosophy 22: 595-619.

Mitchell, R., Agle, B., and Wood, D. 1997. Toward a theory of stakeholder identification and salience: Defining the principle of who and what really counts. Academy of Management Review 22: 853-886.

Myers, F. 1999. Political argumentation and the composite audience: A case study. Quarterly Journal of Speech 85: 55-71.

Palmieri, R. 2008. Reconstructing argumentative interactions in M\&A offers. Studies in Communication Sciences 8(2): 279-302.

Palmieri, R. 2012. The diversifying of contextual constraints and argumentative strategies in friendly and hostile takeover bids. In Exploring argumentative contexts, ed. F.H. van Eemeren, and B. Garssen, 343-375. Amsterdam/Philadelphia: John Benjamins. 
Palmieri, R. 2014. Corporate argumentation in takeover bids. Amsterdam: John Benjamins.

Palmieri, R., and C. Palmieri. 2012. Text types, activity types and the genre system of financial communication. In Les discours de la bourse et de la finance. Forum für Fachsprachen-Forschung, ed. L. Gautier. Berlin: Frank und Timme.

Palmieri, R., A. Rocci, and N. Kudrautsava. 2015. Argumentation in earnings conference calls. Corporate standpoints and analysts' challenges. Studies in Communication Sciences 15(1): 120-132.

Park, D.B. 1982. The meanings of "audience". College English 44(3): 247-257.

Perelman, C., and L. Olbrecths-Tyteca. 1969. The new rhetoric: A treatise on argumentation. Notre Dame, IN: University of Notre Dame Press.

Post, J.E., L.E. Preston, and S. Sachs. 2002. Redefining the corporation: Stakeholders management and organizational wealth. Stanford: Stanford University Press.

Rawlins, B.L. 2006. Prioritizing stakeholders for public relations. Miami: Institute for Public Relations. http://www.instituteforpr.orgfiles/uploads/2006_Stakeholders.pdf.

Rigotti, E. 2008. Locus a causa finali. In Word meaning in argumentative dialogue. Special issue of L'analisi linguistica e letteraria, vol XVI(2), eds. G. Gobber, S. Cantarini, S. Cigada, M.C. Gatti, S. Gilardoni, 559-576.

Rigotti, E., and A. Rocci. 2006. Towards a definition of communication context. Foundations of an interdisciplinary approach to communication. Studies in Communication Sciences 6(2): 155-180.

Rigotti, E., and S. Cigada. 2013. La comunicazione verbale. 2nd ed. Milano: Apogeo.

Rocci, A. 2009. Manoeuvring with voices: The polyphonic framing of arguments in an institutional advertisement. In Examining argumentation in context: Fifteen studies on strategic maneuvering, ed. F.H. van Eemeren, 257-283. Amsterdam: Benjamins.

Rocci, A., S. Greco, and R. Palmieri. 2015. Argumentative patterns in Swiss Direct Democracy. Paper presented at the 2015 Amsterdam-Lugano colloquium on argumentation theory. Lugano: USI.

Ross, S.A. 1973. The economic theory of agency: The principal's problem. The American Economic Review 63(2): 134-139.

Ross, W.D. 1958. Aristotle. Topica et sophistici elenchi. Oxford: Oxford University Press.

Ross, W.D. 1959. Aristotle. Ars Rhetorica. Oxford: Oxford University Press.

Schriver, K.A. 1992. Teaching writers to anticipate reader's needs: A classroom-evaluated pedagogy. Written Communication 9(2): 179-208.

Searle, J.R. (1995). The construction of social reality. London: Penguin Books.

Shannon, C.E., and W. Weaver. 1963. The mathematical theory of communication. Urbana: The University of Illinois Press.

Shoemaker, P., and T. Vos. 2009. Gatekeeping theory. New York: Routledge.

Tindale, C. 2004. Rhetorical argumentation: Principles of theory and practice. Thousand Oaks: Sage.

Tindale, C. 2006. Constrained maneuvering: Rhetoric as a rational enterprise. Argumentation 20: 447-466.

Trautwein, F. 1990. Merger motives and merger prescriptions. Strategic Management Journal 11: 283-295.

Uspenskij, B. 2008. Deissi e comunicazione: la realtá virtuale del linguaggio. Firenze: Firenze University Press.

Van Eemeren, F.H. 2010. Strategic maneuvering in argumentative discourse. Amsterdam: John Benjamins Publishing.

Van Eemeren, F.H., and R. Grootendorst. 2004. A systematic theory of argumentation: The pragmadialectical approach. Cambridge: Cambridge University Press.

Van Eemeren, F.H., R. Grootendorst, S. Jackson, and S. Jacobs. 1993. Reconstructing argumentative discourse. Tuscaloosa, AL: University of Alabama Press.

Van Eemeren, F.H., and P. Houtlosser. 2002. Strategic maneuvering. Maintaining a delicate balance. In Dialectic and rhetoric: The warp and woof of argumentation analysis, ed. F.H. van Eemeren, and P. Houtlosser, 131-159. Dordrecht: Kluver.

Van Rees, M.A., and E. Rigotti. 2011. The analysis of the strategic function of presentational techniques. In Keeping in touch with pragma-dialectics, ed. E. Feteris, et al., 207-229. Amsterdam/Philadelphia: John Benjamins Publishing Company.

Walton, D.N., and E.C.W. Krabbe. 1995. Commitment in dialogue. Basic concepts of interpersonal reasoning. Albany: State University of New York Press.

White, D. 1997. The Gate Keeper: A Case Study in the Selection of News. In Social Meanings of News: A Text-Reader, ed. D. Berkowitz, 63-71. Thousand Oaks: Sage Publications.

Winterbottom, M. 1970. Quintilian. Institutio Oratoria. Oxfrod: Clarendon.

Zarefsky, D. 2008. Strategic maneuvering in political argumentation. Argumentation 23(3): 317-330. 